\title{
NEW COUNTER-TERRORISM LEGAL INSTRUMENTS UNDER THE AUSPICES OF THE INTERNATIONAL CIVIL AVIATION ORGANIZATION
}

\section{ICAO - introductory remarks}

Recently we witnessed the 10th anniversary of the September 11 attacks - the world most terrifying proofs of the existence of the unlimited powers of global terrorism. - In connection therewith, it is worth taking a look at the status of instruments developed by the International Civil Aviation Organization (ICAO) one year earlier, during the International Conference on Air Law held between August 30 and September 10, 2010, in Beijing. In order to do so, one must first realize the path of other legal actions taken in the field prior to 2010.

The International Civil Aviation Organization was established under the provisions of the Chicago Convention on International Civil Aviation signed in 1944 (the Organization started to function in 1947) with goals which among others listed: insurance of the safe and orderly growth of international civil aviation throughout the world, meeting the needs of the peoples of the world for safe, regular, efficient and economical air transport, promotion of safety of flight in international air navigation. ${ }^{1}$ Although the word "terrorism" does not appear in the list of the ICAO's goals (which would most definitely have been the case had the Organization been established 20 years later, after a series of aircraft highjackings occurred and shaped a real threat to civil aviation), the repeated use of "safe" and "safety" terms stand for the ideal description of civil aviation. Back then, the aim was to make and keep air flying and air travel safe, whereas today it would be to counter terrorism and make sure the preventive and protective measures are properly scaled and applied. Well arranged, carefully planned and properly managed cooperation of states interested in efficient development of civil aviation was required to make it actually happen for

1 Article 44 of the Convention on International Civil Aviation signed in Chicago on December 10, 1944, ICAO Doc. $7300 / 7$. 
the world interest. The effective and inspiring management was to come from the creation of the International Civil Aviation Organization, which was an "ambitious dream" of delegates gathered in Chicago in 1944. ${ }^{2}$ Today, ICAO operates under the aegis of the United Nations and gathers together a total of 190 member states covering the entire global aviation community.

\section{Accomplishments of ICAO in the treaties of the 1960s and 1970s}

For almost the first 20 years of its operation, ICAO was not pressed to focus too much attention on aviation terrorism although the creation of safety and security standards was one of the major tasks the Organization worked on. Starting in the late 1950s in Cuba and early 1960s in the USA, the highjackin of commercial aircraft became an instrument used for political reasons and for making political statements. ${ }^{3}$ Member states of ICAO began to hold a series of meetings and conferences, drafting a multilateral convention that would provide necessary instruments to deal with such situations. The final version of the convention was introduced and opened for signature during a during a conference in Tokyo in September 1963, and the Convention on Offences and Certain Other Acts Committed on Board Aircraft came into force in $1969^{4}$. It was the first international treaty aiming to provide solutions to combat highjackings and since terrorist groups carried out a number of the incidents, it was also the first universally accepted treaty on counter-terrorism. ${ }^{5}$ It is now considered the first step toward the regulation of aviation counter-terrorism measures. As such it is far from being comprehensive, complex and covering all of the issues. The Tokyo Convention applies to offences against penal law and acts which, whether or not they are offences, may or do jeopardize the safety of the aircraft or of persons or property therein or which jeopardize good order and discipline on board (article 1 p. 1). The Convention deals with jurisdiction over offences and acts committed on board granting it to the State of the aircraft registration (articles 3-4). It also provides (for the first time in the legal history of aviation) powers of the aircraft commander listing reasonable measures including restraints that are necessary i.e. to protect the safety of the aircraft, or of persons or property therein or to maintain good order and discipline on board (articles 5-10). In case of an unlawful seizure of aircraft, the Convention entitles Contracting States to take all appropriate measures to restore control of the aircraft to its lawful commander or to preserve his control of the

2 On the details of the Chicago Conference arrangements see: D. MacKenzie: ICAO: A history of the International Civil Aviation Organization, University of Toronto Press Incorporated 2010, p. 26 and next.

3 Between years 1948-1960 there were 29 successful aircraft hijackings, between years 1961-1967- total of 16 and in 1968 alone the number raised to 33. See: P. Dempsey: Aviation security: the role of law in the fight against terrorism, 41 Colum. J. Transnat'I L. 649 (2003), p. 654.

4 Convention on Offences and Certain Other Acts Committed On Board Aircraft, signed in Tokyo on September 14, 1963, ICAO Doc 8364.

5 J. Huang: Aviation Safety through the Rule of Law. ICAO mechanisms and practices, Wolters Kluwer 2009, p. 112. 
aircraft (article 11). Powers and duties of states in terms of dealing with a person who has committed the offences under jurisdiction of the Convention are also described including some extradition issues without however obligation of the extradition of persons committing the offences (articles 12-15). The Tokyo Convention was an important step in the regulation of counter-terrorism measures. It has been signed and ratified by 185 countries. The high number of contracting states proves that international society needed such solutions but it also says that, being quite general in its provisions, the Tokyo Convention was easily adopted and could be differently interpretated. It certainly lacked precise details (no list or examples of offences were given) and covered only limited actions that is offences committed or acts done by a person on board any aircraft registered in a Contracting State, while that aircraft is in flight or on the surface of the high seas or of any other area outside the territory of any State (article 1 p. 2).

An attempt to remedy the deficiencies of the Tokyo Convention was made in 1970, when after the intensification of aircraft hijackings in the late 1960s, member states of ICAO signed another universally binding treaty. ${ }^{6}$ This time the final conference was organized in the Hague and succeeded in the introduction of the Convention for the Suppression of Unlawful Seizure of Aircraft ${ }^{7}$.

In the opening provisions, the unlawful seizure of aircraft (hijacking) is defined and qualified as an offence. In addition, contracting states are said to take steps to make such offence punishable by severe penalties (articles 1-2). The Hague provisions extended jurisdiction provided in the Tokyo Convention to the following situations: when the offence is committed on board an aircraft registered in that State, when the aircraft on board which the offence is committed lands in its territory with the alleged offender still on board and when the offence is committed on board an aircraft leased without crew to a lessee who has his principal place of business or, if the lessee has no such place of business, his permanent residence, in that State (article 4 p. 1). Taking the offender to custody or taking other measures to ensure his presence until criminal or extradition procedures are carried out, is established as the obligation of a state in the territory of which such person is present. The aut dedere aut punire clause was clearly stated. Moreover, the Convention imposes obligation to include the offence of unlawful seizure as an extraditable offence in any extradition treaty existing between contracting states (articles 6 and 8). Interestingly, the complex section on extradition included in article 8 of the Convention, was later used as the model extradition provision in several United Nations' counter-terrorism

\footnotetext{
6 The need for the supplementation of the Tokyo resolution was very real as proved by the fact that the Hague Convention came in force in 1971. A year is a relatively short period for the completion of required ratifications in member states (to compare it took member states 6 years to finalize the ratification of the Tokyo Convention).

7 Convention on for the Suppression of Unlawful Seizure of Aircraft, signed at The Hague on December 16, 1970, ICAO Doc 8920.
} 
conventions. ${ }^{8}$ Recognized as an enforcement-oriented and valuable element of the world's legal artillery against unlawful interference with civil aviation, the Hague Convention is also criticized for non-sufficient definition of the "offence", failure to address acts of terrorism preceding the flight, or the conclusion that it does not apply to a situation where a hijacker commandeers an international flight and has it land in the country of its departure. It is also criticized for the failure to cover unlawful interference with air navigation, facilities and services such as airports, air control towers or radio communications. ${ }^{9}$ Despite inevitable deficiencies, the Hague Convention is a universally binding document with 185 contracting states party to it.

The Tokyo-Hague duet was very soon supplemented with the third international treaty dedicated to the safety of international civil aviation. Again, under the auspices of the International Civil Aviation Organization, a series of meetings were scheduled to arrive at a final draft of the Convention for the Suppression of Unlawful Acts Against the Safety of Civil Aviation introduced on September 23, 1971, at the conference in Montreal. ${ }^{10}$ It entered into force two years later and imposes rights and obligations on the 188 states that ratified the document.

The main purpose of the Montreal Convention was to provide regulations concerning sabotage committed on the ground, as well as unlawful interference with air navigation facilities and services as none of the earlier treaties covered those issues. In the first article the Convention lists acts regarded as offences once committed unlawfully and intentionally including: act of violence against a person on board an aircraft in flight if that act is likely to endanger the safety of that aircraft, destruction of an aircraft in service or damage to such an aircraft which renders it incapable of flight or which is likely to endanger its safety in flight, placement on an aircraft in service, by any means whatsoever, a device or substance which is likely to destroy that aircraft, as well as cause damage to it which renders it incapable of flight, or damage to it which is likely to endanger its safety in flight, destruction or damage of air navigation facilities or interference with their operation, if any such act is likely to endanger the safety of aircraft in flight, communication of false information thereby endangering the safety of an aircraft in flight (article 1 p. 1). Just as in the Hague Convention, each contracting state has to implement measures for the above listed offences to be punishable by severe penalties (article 3) and, just as in the Hague text, the term "severe penalties" is not defined. Further, the Convention clarifies which flights are under its force excluding of course military, customs and police services and narrowing its scope to cover only those air navigation facilities

8 C.C. Joyner, International Extradition and Global Terrorism: Bringing International Criminals to Justice, 25 Loy. L.A. Int'l \& Comp. L. Rev. 493 (2003), p. 512.

9 Arguments brought among others by: R.I.R. Abeyratne: Attempts to ensure peace and security in international aviation, 24 Transp. L.J. 27 (1996), p. 53-54 and P. Dempsey, Aviation, op .cit, p. 668.

10 Convention for the Suppression of Unlawful Acts against the Safety of Civil Aviation, signed in Montreal on September 23, 1971, ICAO Doc 8966. 
in action, which are used in international air navigation (article 4). Solutions similar if not identical to those implemented by the Hague Convention are included in the 1973 document with regards to the jurisdictional powers of the contracting states and the extradition or prosecution rules. As noted by several observers, including R.I.R. Abeyratne, and pointed as the weakness of the Montreal system, prosecution is not mandatory when proper analysis of the provisions are applied as it does not mandate the actual prosecution of the offender but merely the submission of the case to the competent domestic prosecuting authorities. ${ }^{11}$

In 1988, a protocol (the so-called Montreal Airports Protoco ${ }^{12}$ ) to the Montreal Convention was signed to encompass terrorist acts at airports serving international civil aviation. There are 171 parties to the Protocol who agreed to add Article 1 bis to the Montreal Convention stating that "Any person commits an offence if he unlawfully and intentionally, using any device, substance or weapon: 1. Performs an act of violence against a person at an airport serving international civil aviation which causes or is likely to cause serious injury or death; or 2. destroys or seriously damages the facilities of an airport serving international civil aviation or aircraft not in service located thereon or disrupts the services of the airport, if such an act endangers or is likely to endanger safety at that airport."

\section{Aviation security in other ICAO activities and actions}

The legal instruments described above constituted the basis for aviation safety worldwide. For many years no binding additional or supplementary documents were signed or negotiated with regards to safety and/or security issues. ${ }^{13}$ It only proves that despite the fact that problems with air terrorism continue to develop, the possibility of compromises and common ideas for counter measures included in binding agreements is difficult to achieve among the international civil aviation players. ${ }^{14}$

It has to be underlined, however, that security of civil aviation has been on the ICA agenda for some time and actions on different levels were undertaken to

11 R.I.R. Abeyratne: Attempts..., op. cit., 62.

12 Protocol for the Suppression of Unlawful Acts of Violence at Airports Serving International Civil Aviation, Supplementary to the Convention for the Suppression of Unlawful Acts against the Safety of Civil Aviation signed at Montreal on 23 September 1971, ICAO Doc 9518.

13 In fact the only convention which came in force since then was the 2001 Convention on International Interests in Mobile Equipment together with the Protocol on Mobile Equipment signed at Cape Town on 16 November, 2011, ICAO Doc 9793 and 9794.

14 The Hague solutions of 1970 were further backed up by members of the G7 expressed in the 1978 Bonn Declaration. The idea was to impose effective sanctions on states which would fail to obey the Hague rules regarding prosecution or extradition of the alleged offenders. 3 years later, the Bonn Declaration was followed by the Montebello Summit Statement on Terrorism signed after tragic events of 2 March 1981 hijacking of the Pakistani plane when 141 passengers were kept for 13 days before dramatic negotiations were finished. M. Milde, International air law and ICAO, Essential air and space law, vol 4, Eleven International Publishing 2008, p. 254-255. 
guarantee safe air travels around the world. The 1944 Chicago Convention is the basic document for the regulation of international civil aviation and it was amended to add basic provisions for strengthening aviation safety and security. There are a total of 18 Annexes to the Convention. The role of the Annexes is to introduce standards and recommended practices ${ }^{15}$ (SARPs) in particular fields including personnel licensing, rules of the air, metrological service, aeronautical charts, telecommunications and information services, units of measurement, operation, nationality and airworthiness of aircraft, air traffic services, search and rescue, aircraft accidents, aerodromes, environmental protection. SARPS, as based on the provisions of the Chicago Convention, do not have the same legally binding force as the articles of the Convention themselves (no ratification is required and they constitute a form of "technical international legislation" - as labelled by several air law specialists). ${ }^{16}$ On the other hand, any departures from international standards (not recommended practices) are to be notified immediately to ICAO. Article 38, provides that states "shall give immediate notification" which is considered as a legally binding obligation.

Annex 17, is titled "Security: Safeguarding International Civil Aviation Against Acts of Unlawful Interference". It had been added to the Convention in 1974 and since then amended 12 times and supplemented by the ICAO Aviation Security Manual. The Annex requires each contracting state to establish its own aviation security program and provides for basic instruments to be used in such program.

It should be emphasized that ICAO also implemented a special auditing program - Universal Security Audit Program (USAP) as a part of ICAO's Aviation Security Plan of Action. USAP provides for mandatory and regular audits of all ICAO Contracting States. The audit is to assess the implementation of the state's security programs. The first round of the USAP began in 2000, the second one in 2008 and is to be concluded in $2013 .{ }^{17}$

\footnotetext{
15 Distinction between an international standard and recommended practice is given in the ICAO Assembly Resolution A 35-14 on Consolidated Statement of Continuing ICAO Polices and Associated Practices Relating Specifically to Air Navigation, Appendix A, ICAO Doc 9849. Both terms mean „any specification for physical characteristics, configuration, material, performance, personnel or procedure" provided for uniform application. In case of international standards the uniform application is recognized as "necessary for" and in case of recommended practices as "desirable in the interest of" the safety or regularity of international air navigation. Articles 37 and 38 of the Chicago Convention. See also: L. Weber, International Civil Aviation Organization. An Introduction, Kluwer Law International 2007, p. 34.

17 See: Universal Security Audit Program (USAP) website: http://www2.icao.int/en/AVSEC/USAP/default.aspx
} 


\section{Post September 11 declarations and statements of ICAO and its member states}

All of the above-described ideas for the safety of aviation have been adopted under the auspices of ICAO but in fact, it was the tragic and shocking events of September 11, 2001, that actually refocused the attention of the world community on the problem of aerial terrorism ${ }^{18}$. During the 33rd Assembly Session, a resolution including a special Declaration on the misuse of civil aircraft as weapons of destruction and other terrorist acts involving civil aviation was adopted as a direct response to the September 11 attacks (the session was held from 25 September to 5 October 2001). The Resolution states that events of September 11 force states to recognize a new threat to civil aviation, which require new concerted efforts and policies of cooperation. It also called upon states to adhere to the ICAO SARPs regarding aviation security and directed the ICAO Council to convene, an international, highlevel, ministerial conference on aviation security with the objectives of preventing, combating and eradicating acts of terrorism involving civil aviation. ${ }^{19}$

Almost a decade later, another Declaration was adopted during the 37th ICAO Assembly session in 2010, inspired by attempted sabotage of Northwest Airlines Flight 253 on 25 December $2009^{20}$. Once again, the ICAO Assembly urged the member states to strengthen and promote SARPs, with particular focus on Annex 17 , to strengthen security screening procedures, to develop and implement enhanced security measures, etc.

A Series of declarations and statements of the President of the ICAO Council21 were only to manifest some of the attitudes and to protest against the spreading force of aerial terrorism. There were several meetings and seminars devoted to the development of technological mechanisms necessary to improve security at airports, which led to actual improvements and changes in the airport procedures. ${ }^{22}$ Member states of ICAO were open to adopt any kind of cooperation strengthening document or to confirm the need to act further. The ICAO's SARPs were amended in accordance with the newest developments. On the other hand, discussions on the possibility to negotiate and adopt a new binding convention or at least - to amend

18 P. Dempsey: Aviation security..., op. cit., p. 649.

19 A33-1 Declaration on misuse of civil aircraft as weapons of destruction and other terrorist acts involving civil aviation, ICAO Doc 9790, Part VII, p. VII-1 and next. See also: R.I.R. Abeyratne, Aviation Security Law, Springer 2010, p. 16-17.

20 Declaration on Aviation Security, ICAO Doc. 9958, Appendix H, p. VII - 14- 15.

21 For example: Address by the President of the Council of the International Civil Aviation Organization (ICAO), Mr. Roberto Kobeh González, to the Bucharest Air Law Conference on "New Challenges and Threats in Civil Aviation", Bucharest, Romania, May 3, 2010, available on the ICAO website at: http://www.icao.int/icao/en/pres/ kobeh/20100503 PRES Bucharest Romania Air Law Conference en.pdf

Those events are still organized, for example a Regional Seminar on Machine Readable Travel Documents (MRTDs), Biometrics and Security Standards held in Mozambique on 24-26 November 2010. For details see ICAO website: http://www.icao.int/MRTDseminar/2010africa/ 
the existing agreements were difficult, if not impossible, for a number of years. In 2005, ICAO convened an ad hoc Secretariat Study Group to identify deficiencies in the existing unlawful interference treaties ${ }^{23}$ (including the Tokyo, Hague and Montreal Conventions of the1960s and 1970s) but then for another 2 years ICAO member states were not able to take any step further. It has to be emphasized that some of the ICAO works and decisions on security standards were strongly opposed by many human rights and civil liberties organizations. ${ }^{24}$ It has been quite a challenge to find a compromise among the 190 member states of ICAO to agree on new legal provisions or to find a common view for the amendments of the existing, yet outdated laws.

\section{Amending the old and drafting the new - ICAO's legal reaction to aerial terrorism in the world}

Between 2008 and 2010 a total of four international conventions regulating civil aviation were either amended or drafted. Two of them regarded issues of civil liability for damages and the other two were dedicated to the changes in the criminal air conventions from 1970 (Montreal) and 1971 (Hague).

The first set of changes was discussed during a meeting in Montreal in 2008. The idea was to draft new conventions dealing with compensations for damage caused by acts of unlawful interference involving aircraft and for damage caused by aircraft to the third parties. They would replace the Rome Convention of $1952^{25}$ that proved to be ineffective. The meeting of the Legal Committee in 2008 was followed by the Legal Seminar organized by the regional ICAO office in Paris a year later and finally - by a diplomatic conference of ICAO held in Montreal in 2009 with 81 participants (members of the ICAO) and representatives of 16 other organizations. The conference was the last step in negotiations and debates over drafts of two conventions: Unlawful Interference Compensation Convention (UIC) ${ }^{26}$ and General Risks Convention (GRC) ${ }^{27}$. The discussions were not easy and even the definitions of basic terms (such as "event", "in flight" or "operator") caused problems. In the

During the meeting it was decided that only the Hague and Montreal treaties can be amended or changed. More see: M. Jennison: The Beijing Treaties of 2010: Building a modern great wall against aviation-related terrorism, 23 No. 3 Air\&Space Law. 9, p. 10.

24 On March 30, 2004 An Open Letter to the ICAO: A second report on "Towards an International Infrastructure for Surveillance of Movement" was published expressing concerns of over 20 organizations from different regions of the world regarding ICAO the screening procedures as well as the biometric measures. The Open Letter is available on the website of the Electronic Frontier Foundation at: https://www.eff.org/files/filenode/rfid/icaoletter.pdf Convention on Damage Caused by Foreign Aircraft to Third Parties on the Surface signed at Rome on 7 October, 1952, ICAO Doc 7364.

26 Convention on Compensation for Damage to Third Parties, Resulting from Acts of Unlawful Interference Involving Aircraft done at Montreal on 2 May 2009, ICAO Doc 9920.

27 Convention on Compensation for Damage Caused by Aircraft to Third Parties done at Montreal on 2 May, 2009,ICO Doc 9919. 
end, on the last day of the conference, only a few states signed the conventions. ${ }^{28}$ There are presently 8 signatories to the UIC and 10 signatories to the GRC (in both cases - mostly African states), and 35 ratifications are needed for those to come in force. ${ }^{29}$

The reviews of the Montreal and Hague conventions from the 1970s were sparked by the September 11 events, yet it was not until when from a series of ICAO meetings it was concluded that the existing international regime did not cover the full range of elements regarding situations such as the attacks on the WTC and Pentagon. What was left outside the scope of the conventions, as noted by D. van der Toorn, was for example the use of aircraft to cause death and destruction, use of weapons of mass destruction onboard, from or against aircraft and other ancillary offences, such as organizing or conspiring to commit such offences. ${ }^{30}$

The Legal Committee of ICAO met in September 2009 to work on the modernization of the Montreal and Hague Conventions and that is when the final texts were prepared. During the meeting it was not decided whether the existing conventions will be amended in forms of protocols or whether new treaties will be adopted replacing the 1970s laws. The need to speed up works on those issues was clearly stated during the meeting emphasizing that it has been 8 years since September 11 happened and the Committee decided to work on two separate documents creating a fully new and complex structure for legal acts. During the meeting several specific legal problems were discussed including the kinds of offences to be covered by new provisions, with special emphasis on so called "transport offences". Some definitions were also not easy to agree to (especially controversial were those regarding biological weapons and dangerous materials), some new ideas (such as additional new jurisdiction for a state whose citizen committed the offence) were not widely supported. Some of the most crucial problems were left to be solved at the final diplomatic conference. ${ }^{31}$

The final diplomatic conference - International Conference on Air Law - was held in Beijing between August 30 and September 10 of $2010^{32} .400$ participants from over 80 states and international organizations attended and worked on many compromises. The first obstacle - that is the form of new provisions (new

28 M. Polkowska: Prace (ICAO) nad modernizacją konwencji, „Jurysta” nr 3, 2000, p. 48-51.

29 As the present article focuses on the criminal issues of the aerial terrorism, the civil liability conventions will not be discusses further. All the 2009 diplomatic conference documents can be fund on the ICAO website at: http:// www.icao.int/DCCD2009/doc.htm. A full analysis of both of the documents is provided, [in:] R.I.R. Abeyratne: Liability for third party damage caused by aircraft - some recent developments and issues, J Transp Secur 2 (2009), p. 91-105.

30 D. van der Toorn: September 11 Inspired Aviation Counter-terrorism Convention and Protocol Adopted, Insights of American Society of International Law, vol. 15, issue 3, January 26, 2010, p. 1.

31 M. Polkowska: Prace (ICAO)..., op. cit., p. 51-53.

32 All the conference documents are available on the ICAO website at: http://www.icao.int/DCAS2010/. A full report on the changes provided by the Beijing instruments is provided, [in:] Widening the Net, ICAO Journal, vo. 6, n. 1, 2011 p. 6-14. 
conventions or amendment of the old ones) - was overcome during the second week of the conference as the so-called "consensus package": a separate document would be adopted replacing the Montreal Convention for the Suppression of Unlawful Acts against the Safety of Civil Aviation and an amending protocol would be added to the Hague Convention for the Suppression of Unlawful Seizure of Aircraft.

As an outcome of the conference in Beijing then, ICAO presented the world with a new Convention on the Suppression of Unlawful Acts Relating to International Civil Aviation ${ }^{33}$ called the Beijing Convention with a total of 25 articles. Article 1 of the Convention introduced a new, extended list of actions regarded as offences if performed unlawfully or intentionally. The new law lists for example, use of "an aircraft in service for the purpose of causing death, serious bodily injury, or serious damage to property or environment" (art. 1 p. 11 . (f) of the Convention) as a direct reflection of the September 11 actions. It also considers as an offence a release or discharge from as well as use against or on board "an aircraft in service any $\mathrm{BCN}^{34}$ weapon or explosive, radioactive, or similar substances in a manner that causes or is likely to cause death, serious bodily injury or serious damage to property or the environment" (art. 1 p. $11 \mathrm{l}(\mathrm{g})-(\mathrm{h})$ of the Convention) ${ }^{35}$. The "transportation offences" were eventually included in the list with a provision that the transportation of some dangerous items and materials (used in nuclear explosive activity) will not be punishable as long as they are transported in accordance with applicable multilateral non-proliferation treaty laws (art. 1 p. 11 . (i) (1)-(4) of the Convention). It is also illegal to communicate false information thereby endangering the safety of an aircraft in flight. The new Convention does not stop the list on the actual action (use, performance, transportation, destruction, damage). It also states that a credible threat to commit such offence is an offence itself, as well as assistance to an offender to evade investigation, prosecution or punishment and that conspiracy to commit an offence, or its equivalent, is also punishable under the new regime (art. 1 p. 3- 4-5 of the Convention). The list included in art. 1 is an answer and an update to the most challenging threats that could be used in aerial terrorism. Article 5 excludes application of the Convention to the aircraft used in military, customs or police services (it was one of the long debated problems throughout the diplomatic conference). The controversial issue of an additional, new jurisdiction for a state whose citizen committed the offence was addressed in art. 8 . As the majority refused to support the opponents of the new possibility, the jurisdiction of such state was left in the provision.

33 Convention on the Suppression of Unlawful Acts Relating to International Civil Aviation, done at Beijing on 10 September 2010, ICAO Doc. 9960

34 Biological, Chemical, Nuclear weapons, precisely defined in article 2 of the Convention - footnote from the Authors.

35 The list of all the applicable treaties is provided in article 7 of ten Beijing Convention. 
Articles 9 through 11 establish procedure which states take when a person accused of committing the listed offences is present in the territory of the state and taken into custody. For the first time, it guarantees the offender fair treatment during any procedures against him (article 11 of the Convention). Extradition principles are included in articles 13 through 14 introducing some new solutions as well. For example, as provided in article 13 "none of the offences set forth in Article 1 shall be regarded, for the purposes of extradition or mutual legal assistance, as a political offence or as an offence connected with a political offence or as an offence inspired by political motives. By art. 14 the offender is protected from discrimination based on race, religion, nationality, ethnic origin, political opinion or gender. In other articles the Convention provides for cooperation and support of states - parties to the Convention to prevent the offences and when they happen - to assist each other. The Convention requires any of the offence to be reported to the ICAO Council.

During the same conference in Beijing, another major change was discussed and adopted. The Protocol Supplementary to the Convention for the Suppression of Unlawful Seizure of Aircraft ${ }^{36}$ (the Beijing Protocol) introduces changes to the existing Hague regime. As a rule, those changes are equivalent to those provided by the new Beijing Convention.

Importantly, the Beijing Protocol replaces article 1 of the Hague Convention and it now states: "Any person commits an offence if that person unlawfully and intentionally seizes or exercises control of an aircraft in service by force or threat thereof, or by coercion, or by any other form of intimidation, or by any technological means" (art. 1 p. 1 of the amended Hague Convention). A threat to commit the mentioned offence is also regarded as an offence along with any attempt, participation as an accomplice, assistance, organization or directing others to commit such offence (article 1 p. 2 and 3 of the amended Hague Convention). Again, each state party is obliged to make the discussed offences punishable by severe penalties (art. 2 of the amended Hague Convention). Interestingly, the Protocol allows the state parties, in accordance with its national legal principles, to take the necessary measures to enable a legal entity located in its territory or organized under its laws to be held liable when a person responsible for management or control of that legal entity has, in that capacity, committed an offence and allows such liability to be criminal, civil or administrative (art. 2 bis addend to the Hague Convention).

Issues of jurisdiction, including the new type of jurisdiction when a national of a state commits the offence, are handled similarly to the solutions in the new Beijing Convention. The same solutions are accepted with regards to procedures against the 
offender in custody, principles of extradition and finally - party states' cooperation and mutual assistance.

\section{Final remarks}

The Beijing Convention received 18 signatories on the day it was adopted and the Protocol was signed on that day by 19 states (including the US, United Kingdom and China). Presently (as of October 2011), 21 states signed the Convention and 23 signed the Protocol. Entry into force of both documents must be preceded by 22 ratification, acceptance, approval or accession procedures of the ICAO member states. The Montreal Convention of 1971 along with its Protocol of 1988, are still in force and will be in force until all of their signatories accept the new Beijing Convention of 2010. Even though only 22 ratifications are required for the binding force of the new laws, it has been emphasized that: "not until they both achieve 180 or more ratifications will we have a truly universal, modern legal regime to address the attacks on civil aviation that will continue to be attempted"37.

Certainly, use of both instruments would be helpful in the world's most dynamic fight against terrorism. It should be regarded as an accomplishment, although the undeniable technical development should not be forgotten. Technology makes air travels safer but it also provides new possibilities for those who want to use aircrafts for dangerous reasons and missions. The ICAO member states have to stay on constant alert as new possibilities and threats are just around the corner or rather, justaround - in cyberspace - the so-called hydra-headed monster that can effect air transport in any number of ways. ${ }^{38}$ 


\section{NOWE PRAWNE INSTRUMENTY ZWALCZANIA TERRORYZMU MIĘDZYNARODOWEJ ORGANIZACJI LOTNICTWA CYWILNEGO}

Celem artykułu jest przedstawienie roli Międzynarodowej Organizacji Lotnictwa Cywilnego w przeciwdziałaniu terroryzmowi lotniczemu. Analizie poddano zapisy Konwencji Tokijskiej będącej pierwszą międzynarodową inicjatywą mająca na celu zapobieganie uprowadzeniom samolotów. Zapisy Konwencji Tokijskiej rozszerzyła Konwencja Haska z 1970 r., ustanawiając m.in. szerszy zakres jurysdykcji oraz zasadę aut dedere aut punie. Konwencje zostały uzupełnione trzecią konwencją podpisaną w Montrealu, która po raz pierwszy wprowadziła regulacje odnoszące się do aktów sabotażu z ziemi czy zakłócenia funkcjonowania urządzeń nawigacyjnych. Pakiet trzech konwencji stanowi podstawę regulacji dotyczących bezpieczeństwa lotnictwa. Wydarzenia z 11 września 2001 r. uaktywniły poczynania Międzynarodowej Organizacji Lotnictwa Cywilnego w zakresie przeciwdziałania terroryzmowi, ale nie przyniosły konkretnych efektów. Dopiero w latach 2008-2010 przygotowano cztery nowe konwencje: dwie odnoszące się do zasad cywilnej odpowiedzialności za szkody oraz dwie wprowadzające zmiany do karnoprawnych konwencji z Montrealu i Hagi.

Key words:

International Civil Aviation Organization, civil aviation, security, aerial terrorism, aircraft accidents 